\title{
Evaluation of Jasmonic Acid Production by Lasiodiplodia theobromae under Submerged Fermentation
}

\author{
Kavitha Mary Jackson*, Marimuthu Ponnusamy and Sivakumar Uthandi \\ Department of Agricultural Microbiology, \\ Tamil Nadu Agricultural University, Coimbatore - 641 003, Tamil Nadu, India \\ *Corresponding author
}

\begin{tabular}{|c|c|}
\hline & A B S T R A C T \\
\hline $\begin{array}{l}\text { Ke y w o r d s } \\
\text { Lasiodiplodia sp., } \\
\text { Jasmonic acid, } \\
\text { Submerged } \\
\text { fermentation, } \\
\text { Defence } \\
\text { signalling. }\end{array}$ & \multirow{3}{*}{$\begin{array}{l}\text { Present study was conducted to evaluate the jasmonic acid (JA) production } \\
\text { capacity of the isolated pathogenic fungus Lasiodiplodia sp. causing leaf blight in } \\
\text { coconut and pod rot in cocoa. The fungal cultures were isolated from the diseased } \\
\text { coconut and cocoa using PDA (Potato dextrose Agar). Morphological } \\
\text { confirmation was done by examining the isolates under microscope, having } \\
\text { obvoidal shape conidia. Jasmonic acid production was compared with standard } \\
\text { culture and evaluated for higher JA production using four different media (Potato } \\
\text { dextrose medium, Potato carrot medium, Nutrient medium and Minimal salt } \\
\text { medium). The results depicted that potato dextrose media recorded the maximum } \\
\text { in terms of growth and basal salt medium recorded higher jasmonic acid (JA) } \\
\text { production under optimized growth conditions. }\end{array}$} \\
\hline Article Info & \\
\hline $\begin{array}{l}\text { Accepted: } \\
21 \text { April } 2017 \\
\text { Available Online: } \\
10 \text { May } 2017\end{array}$ & \\
\hline
\end{tabular}

\section{Introduction}

Jasmonic acid (JA) play a vital role in molecular plant pathogen interaction and act as a elicitor for induced systemic resistance (ISR) and induces series of defense signaling cascade when pathogen attack occurs. Similar defense mechanism also present during insect and nematode attack. This JA produces in nano and picomolor amount during plant pathogenic interaction. Different fungi are reported as producers of jasmonates such as Botryodiplodia theobromae (Lasiodiplodia theobromae) and Gibberella fujikuroi. JA was first isolated from the culture filtrate of Lasiodiplodia theobromae (Alderidge et al., 1971). G. fujikuroi was reported as producer of a mixture of $\mathrm{N}$-jasmonyl-isoleucine and $\mathrm{N}$ - dihydrojasmonyl-isoleucine (Miersch et al., 1987). Fusarium oxysporum was reported as producer of more than 20 jasmonates and Aspergillus niger grown on liquid medium could form more than 25 jasmonate compounds upon application of JA, 9,10dihydro-JA and their methyl esters (Wasternak, 2007).

Lasiodiplodia theobromae was first described from Theobromae cacao fruit in Ecuador in the late 1800s (Patouillard and Lagerheim, 1892). It is recognized as an important plant pathogen of many woody and herbaceous hosts, especially in the tropical and subtropical region and symptoms include 
dieback, canker, gummosis, leaf blight, root and collar rot of woody plants and agricultural crops (Sinclair and Lyon, 2005). L. theobromaeis predominantly a latent pathogen, frequently found as an endophyte in healthy plant tissue, but that can become a virulent pathogen when the host is weakened or stressed (Mullen et al., 1991; Sinclair and Lyon, 2005). L. theobromae can be distinguished based on their conidia size (Burgess et al., 2006). Lasiodiplodia has slightly wider and more obovoid conidia. A study of Dhandhukia and Thakkar (2006) reveals that optimum temperature and $\mathrm{pH}$ for growth of $L$. theobromae were found as $30^{\circ} \mathrm{C}$ and 5.5, respectively. Regardless of its pathogenic nature $L$. theobromae have the potential to induce jasmonate mediated defense signaling against plant pathogen. Hence present investigation envisage to explore the defense potential of this pathogen and to maximize the Jasmonic acid production by altering the nutrition and other growth conditions.

\section{Materials and Methods}

\section{Isolation and morphological characterization of fungus}

The fungal cultures were isolated and purified from the diseased coconut (leaf blight) and cocoa (pod rot, dieback) collected from Pollachi region, Tamil Nadu, India using PDA. Isolated cultures were confirmed by amplification of ITS 1 and ITS 4 primers. Standard culture was obtained from MTCC (L. theobromae: MTCC 3068) and maintained in PDA. Morphological observations of conidia were done under microscope. Mycelial tips were placed into the PDA medium and were incubated for thirty days at room temperature. After fungal germination occurs, conidia were collected and observed under a light microscope. The conidial morphology was studied and their shape, color and presence of septation were recorded.

\section{Fermentation and optimization of cultural conditions}

L. theobromae was grown in $100 \mathrm{ml}$ potato dextrose broth in $250 \mathrm{ml}$ conical flask by transferring a disc containing actively growing fungal mycelia and incubated for 3 days at $25 \pm 2^{\circ} \mathrm{C}$ in dark. After that the fungus was cultured in potato dextrose broth, potato carrot broth, nutrient broth and minimal salt medium with the addition of $2 \%$ mother culture. $\mathrm{pH}$ of the culture was set as 5.5 and fermentation was carried out in $250 \mathrm{ml}$ Erlenmeyer flasks containing $100 \mathrm{ml}$ sterile medium at $25 \pm 2{ }^{\circ} \mathrm{C}$ in dark for 7 days.

\section{Growth determination}

Biomass production was determined by dry weight after broth filtered on pre-weighted Whatman No.1 filter paper followed by drying at $60^{\circ} \mathrm{C}$ for $24 \mathrm{~h}$.

\section{Extraction and measurement of JA}

At the end of incubation period, mycelia were separated from the culture filtrate using muslin cloth, and filtrates were separated by adding equal volume of ethyl acetate. Organic phase was removed by separating funnel and condensed using rotary evaporator. The organic extracts were resuspended in $1 \mathrm{ml}$ of HPLC grade methanol, filtered through $0.22 \mu$ filters (Hi-media) and analyzed using high performance liquid chromatography. The mobile phase consisted of acetonitrile: methanol: 2-propanol $(95: 3.5: 1.5)$ and the flow rate was $1 \mathrm{ml} / \mathrm{min}$.

\section{Result and Discussion}

The isolated cultures were identified as Lasiodiplodia by its ovoidal shape conidia 
observed under stereo zoom microscope and confirmed by ITS1 and ITS 4 primer amplification. The isolate and standard were subjected to further fermentation studies. Dry matter production was higher in potato dextrose broth $(1.97 \mathrm{~g} / 0.1$ l) followed by minimal salt broth $(1.89 \mathrm{~g} / 0.1 \mathrm{l})$ and least value (were recorded in nutrient broth $1.53 \mathrm{~g} / 0.1 \mathrm{l})$. Similarly higher JA production was recorded in minimal salt broth $(50.77$ $\mu \mathrm{g} / 0.1 \mathrm{l}$ ) followed by potato dextrose broth $(50.71 \mu \mathrm{g} / 0.1 \mathrm{l})$ and least value were recorded in nutrient broth $(49.32 \mu \mathrm{g} / 0.1 \mathrm{l})$. The results has close conformity with the results of Grolamys et al., (2014), shows JA was found at concentrations between 48 and $100 \mu \mathrm{g} \mathrm{mL}^{-1}$ in fermentation broths of Botryodiplodia strains.

Table.1 JA production in submerged fermentation

\begin{tabular}{lcccc}
\hline Medium & $\begin{array}{c}\text { Isolate } \\
\mathrm{DMW}(\mathrm{g} / 0.1 \mathrm{l})\end{array}$ & $\begin{array}{c}\text { Isolate } \\
\mathrm{JA}(\mu \mathrm{g} / 0.11)\end{array}$ & Standard \\
\hline Potato dextrose broth & 1.97 & 1.73 & 50.71 & 52.12 \\
Potato carrot broth & 1.82 & 1.82 & 50.21 & 52.12 \\
Nutrient broth & 1.53 & 1.56 & 49.32 & 51.21 \\
Minimal salt broth & 1.89 & 1.88 & 50.77 & 53.31 \\
\hline
\end{tabular}

Fig.1a\&b Chromatogram of JA (standard) and Chromatogram of culture filtrate
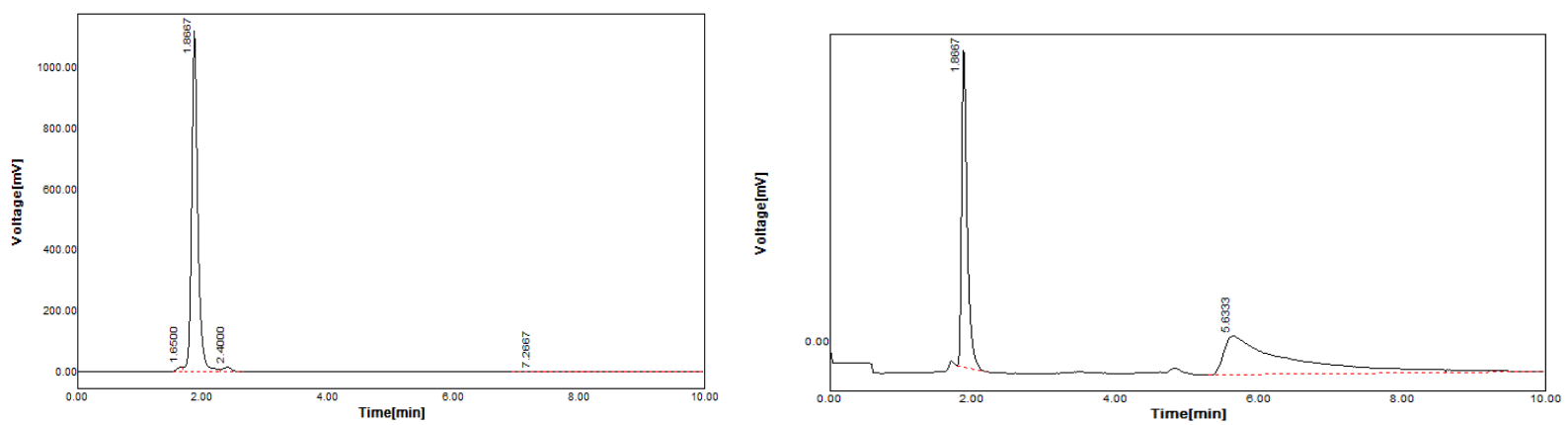

Plate.1a\&b Lasiodiplodia theobromae and microscopic observation of conidia
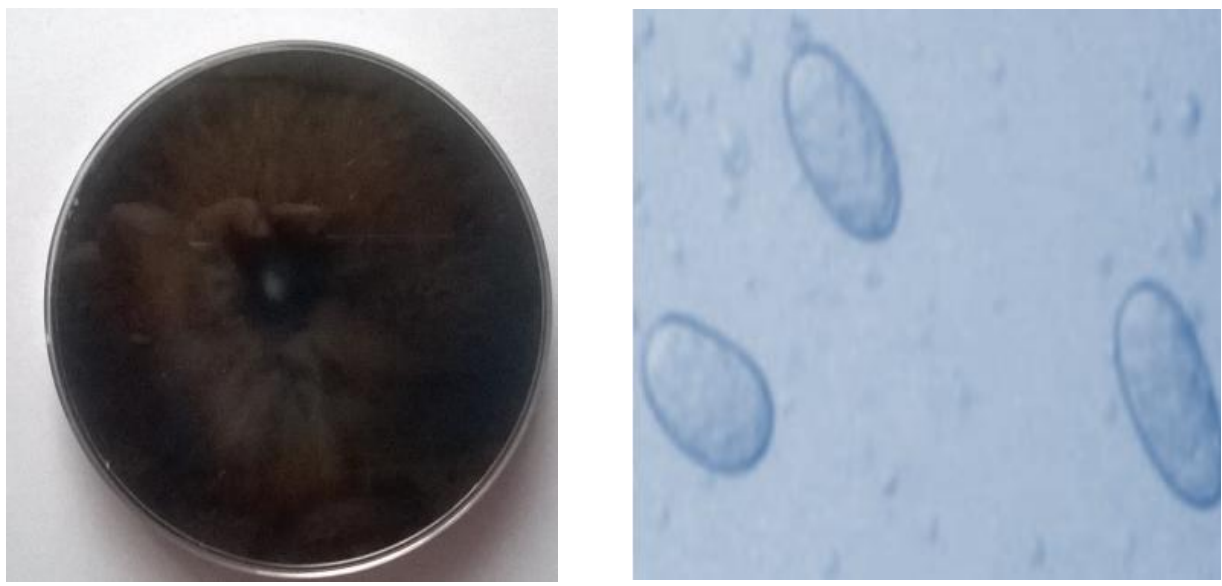
A study of Dhandhukia and Thakkaar (2007a,b) reveals that 5 and $10 \mu \mathrm{L}$ of samples, JA was found to be 14.157 and $30.357 \mu \mathrm{g}$, respectively and JA produced by $L$. theobromae on the seventh day was 30.357 $\mathrm{mg} / \mathrm{L}$ of FCF. JA production of isolate was comparable with standard culture also. Negligible amount of differences existed between standard and isolate (Table 1). Extracted jasmonic acid was analyzed through HPLC along with standard JA.

Jasmonic acid was extracted and separated from Lasiodiplodia theobromae and analyzed through HPLC. Standard jasmonic acid (Sigma) was run at different concentrations and retention time (RT) of JA was near 2 minute (1.8667) and the sample (extracted JA from Lasiodiplodia theobromae) peak also obtained near 2 minute (1.866), which confirms the presence of jasmonic acid (JA) in the sample. Negligible amount of peaks were also recorded from sample chromatogram which shows Lasiodiplodia contains other metabolites along with JA (Fig. $1)$.

In conclusion, the fungus $B$. theobromae has been studied by different authors (Eng et al., 1998; Dhandhukia and Thakkar, 2007a,b, Saha et al., 2008; Jernerén et al., 2012) in order to identify and quantify JA and related compounds. In this study, submerged fermentation of the fungus evaluated for higher levels of JA using four different media.

The JA concentrations found in our fermentation broths are similar to those obtained in other studies with the same fungus species (Dhandhukia and Thakkar, 2007a). Exogenous application of JA in millimolar concentrations increases the resistant against plant pest and diseases. Hence this bioproduct will have the potentiality to become an effective bio control agent. Since it is a plant pathogen genetic modification also needed for effective utilization by the end users.

\section{Acknowledgement}

The authors are grateful to the Ministry of Human Resources Development (MHRD), New Delhi for providing financial assistance to undertaking this research.

\section{References}

Aldridge D, S., Gatts, D. Giles, W.B. Turner.1971. Metabolites of Lasiodiplodia theobromae. J. Chem. Soc., C: 1623-1627.

Dhanhukia, P.C., V.S. Thakkaar. 2007a. Standardization of growth and fermentation criteria of Lasiodiplodia theobromae for production of jasmonic acid. Afr. J. Biotechnol., 6:707-712.

Dhanhukia, P.C., V.S. Thakkaar. 2007b. Response surface methodology to optimize the nutritional parameters for enhanced production of jasmonic acid by Lasiodiplodia theobromae. J. Appl. Microbiol., 105: 636-643

Eng F, Gutiérrez-Rojas M and Favela-Torres E.1998. Culture conditions for jasmonic acid and biomass production by Botryodiplodia theobromae in submerged fermentation. Process Biochem., 33:715-720.

Jerneren, F., F. Eng, M. Hamberg and E.H. Oliw. 2012. Linolenate 9R-dioxygenase and allene oxide synthase activities of Lasiodiplodia theobromae. Lipids, 47:65-73.

Miersch, O., A. Preiss, G. Sembdner and K. Shereiber. 1987. (+)-7-Isojasmonic Acid and Related Compounds from Botryodiplodia theobromae. Phytochemistry, 26:1037-1039.

Patouillard, N., G. Lagerheim. 1892. Champignons de l'Equateur. Bulletin de la SocieteMycologique de France, 8:113-140.

Saha, A., P. Mandal, S. Dasgupta, D. Saha. 2008. Influence of culture media and environmental factors on mycelial 
growth and sporulation of Lasiodiplodia theobromae (Pat.) Griffon and Maubl. $J$. Environ. Biol., 29:407-410.

Sinclair,W.A. and H.H. Lyon. 2005. Diseases of trees and shrubs. Cornell University Press, NewYork.
Wasternack, C. 2007. Jasmonates: An update on biosynthesis, signal transduction and action in plant stress response, growth and development. Ann. Bot., 100:681697.

\section{How to cite this article:}

Kavitha Mary Jackson, Marimuthu Ponnusamy, Sivakumar Uthandi. 2017. Evaluation of Jasmonic Acid Production by Lasiodiplodia theobromae under Submerged Fermentation. Int.J.Curr.Microbiol.App.Sci. 6(6): 1635-1639. doi: https://doi.org/10.20546/ijcmas.2017.606.191 